\title{
Gender And Career Visibility Amongst Female Journalists in Selected National Newspapers In Lagos State, Nigeria
}

\author{
Allen Nnanwuba Adum \\ Department of Mass Communication, Nnamdi Azikiwe University, Awka, Anambra State, Nigeria \\ an.adum@unizik.edu.ng \\ Jennifer Ifeoma Ijei \\ Department of Mass Communication, Nnamdi Azikwe University, Awka, Anambra State, Nigeria \\ Email: jennyijeife@gmail.com
}

\begin{abstract}
This study investigated gender and career visibility amongst female journalists in selected national newspapers in Lagos State, Nigeria. Stated differently, the research aimed at establishing the visibility level of female practicing journalists not just in number but positions occupied by them in the print media industry. Situated within the framework of Socio-cultural Theory and Gender Development, the study adopted the in-depth interview method and survey method. A sample of 57 respondents was selected from the 7 commonly known national newspaper organisations in Lagos State, Nigeria. For the survey aspect, 17 out of 57 Questionnaire was compiled through google survey while the remaining 40 were collected physically by the researcher. However, data were collected using a semi- structured interview guide for the in-depth interview. Findings indicated that there is a large difference in the number and positions occupied by both practicing gender in the print media and the above difference is as a result of one's passion, dedication, efficiency and result produced in term of number of bylines. Also, the distribution in the category of both soft and hard news is based on one's preference or interest of writing. In addition, some of the issues raised as factors limiting their career visibility were marriage, family, tradition, security issues amongst others. The study recommended, among others, that adequate security should be provided for the female practicing journalists who has shown interest and persistence in digging out relevant information from a dangerous environment.
\end{abstract}

Keywords: Gender, Career, Visibility, Journalists.

DOI: $10.7176 / \mathrm{JCSD} / 66-07$

Publication date:November 30th 2021

\subsection{Introduction}

This research focused on gender and career visibility amongst female journalists in the print media industry. Visibility in this study referred to the number of female journalists and positions occupied by them in various print media organisations in Nigeria. Taking a look at the total number of persons registered under the Nigerian Union of Journalists (NUJ), Lagos Council in 1980, 354 persons were registered out of which 349 were males and 5, females (http://nuj.org.ng/compendium). With the above result, one would easily detect the low level of visibility of the female gender in the media industry.

Nevertheless, the global media monitoring project survey carried out on gender dimension of news during the global pandemic, has shown that there was a slight increase in the number of females read and heard about on online, television and radio media. Although the survey carried out by the global media monitoring project 2020 did not showcase a figure on the gender dimension of news in the print media unlike the survey carried out by the gmmp in 2015 (Gmmp-reports, 2020).

It is as a result of the above that the researcher aimed at measuring career visibility with a focus on female Journalists in selected national dailies in Lagos state, with the aim of lending credence to similar research works carried out by scholars.

\subsection{Statement of the Problem}

Currently, a vast majority of journalism graduates is female (Boateng, Kodwo Jonas Anson. 2017). Nevertheless, gender dynamics in journalism are still asymmetric; in most countries, only a small percentage of female journalists make up the media landscape (Edström Maria 2017; Usher Nikki, Jesse Holcomb and Justin Littman 2018). The Global Media Monitoring Project (2015) showed that worldwide, women only report around $37 \%$ of all stories in print, television, and radio combined. Additionally, previous research found that the majority of 
women in the newsroom are delegated to cover stereotypical female topics (e.g., lifestyle and fashion) while men continue to dominate male topics (e.g., technology and economics, see North Louise 2016; Steiner Linda 2012).

The struggle for equality between the male and the females in the media industry has been an enigma as it has continued to be a universal phenomenon, the origin of which cannot be easily stated. In Nigeria, it is perceived that women constitute the majority of the category of persons sidelined. Okunna (1992) states that "...a combination of cultural and religious factors has reduced women to mere appendages of their male counterparts" (p. 49). This claim has lent credence in numerous studies (Malik, 2002; Amuche, 2015; Enwefah, 2016; Safa \& Akter, 2015). In fact, there is an unprecedented surge of women in the practice and agitation for not only greater inclusion and involvement at leadership and decision levels but also in the agitation for a balanced male-female representation in different capacities in the profession (Anorve, 2012, Sanusi \& Adelabu, 2015; Gray \& Hessell, 2014).

Gender audit of major newspapers in Nigeria by journalists for Christ (JFC) international outreach in commemoration of the 2019 International Women's Day on the 3rd of March, 2019 confirmed that only very few women occupy top editorial positions in the country. Also stating that reportage of women in the media is generally low. The above trend is one of the justifications for the campaign theme of the 2019 International Women's Day celebration which is \#Balanceforbetter. The above result shows that, greater inclusion and involvement at leadership and decision level agitated for by the females in various field have proved futile as women are still yet to excel. Could there be a reason behind the above results? Could this be same in the print media because the global media monitoring project survey carried out on gender dimension of news during the global pandemic, has shown that there was a slight increase in the number of females read and heard about on online, television and radio media but the survey carried out by the global media monitoring project 2020 did not showcase a figure on the gender dimension of news in the print media unlike the survey carried out by the gmmp in 2015 (Gmmp-reports, 2020).

The quest to know what could be standing has a hindrance to the career progress of practicing female journalists in the print media brought forth integral questions such as; To what extent female journalists employed in Nigerian national dailies enjoy career visibility? Is gender a factor in the career visibility of these female journalists? What has been the response of the female journalists to the possible hindering effect of gender on their career visibility? Though seemingly simple on the surface, these questions open up a discussion that digs deep into the underlying thinking of researchers.

\subsubsection{OBJECTIVES OF THE STUDY}

The following objectives guided the study:

1. To find out the extent female journalists employed in Nigerian national dailies enjoy career visibility in Lagos state.

2. To ascertain the extent gender is a factor in the career visibility of these female journalists in Lagos state.

3. To find out the response of the female journalists to the possible hindering effect of gender on their career visibility in Lagos state.

\subsubsection{RESEARCH QUESTIONS}

1. To what extent do female journalists employed in Nigerian national dailies enjoy career visibility in Lagos state?

2. To what extent is gender a factor in the career visibility of these female journalists in Lagos state?

3. What is the response of the female journalists to the possible hindering effect of gender towards achieving career visibility in Lagos state?

\section{Literature review}

\subsection{Career Visibility of Women in the Media [Global Trend]}

As the preliminary study revealed, to improve the representation, more women have to enter the media industry. The general public expected more women in media and journalism to counter the negative gendered stereotypes of in the media. Consequently, now there are increasing women as journalists, editors, designers and so on. Even in the tools of production where women were previously often denied have now access and are capable of using them (Humphrey \& Vered, 2014). Disappointingly, despite women 's greater presence in newsrooms, the landscape of news has changed very little over the past decade, notwithstanding research evidence which suggests that what the news media provide to the consumer is not necessarily what she wants (Ross \& Carter, 
2011). Rajeev, Midhila and Karthika (2019) carried out a research on work and life of women journalists: a study with special reference to kerala. The major purpose of the above study was to discuss the gender discrimination and inequality bestowed on a female journalist in the media field. The study examined the physical challenges faced by women journalists and focused on their security issues and legal supports demanded by them. This study brought out the wage issues and psychological problems faced by the female media professionals, with special reference to the state of Kerala. The study points out the inevitable need in enhancing the legal system in order to provide a safe ground for the aspiring women in the country. By motivating them, we motivate the nation.

A research carried out by Gallaghar (1995) showed that there were only $12 \%$ of women in top management positions in the 239 companies she examined but later the status of women in news industry has improved as the global report on the status of women in the news media notes that women constituted only one-third of the fulltime journalism workforce and one-fourth in the top management positions (International Women 's Media Foundation, 2011). This figure is still far away to reach the equal representations. However, the findings of global media monitoring project (GMMP) that monitors the news output in print and broadcasting media, showed that number of women reporters were increasing and more than half of the empowering stories on women were written by women reporters (Gadzekpo, 2009). Before publishing the news or narratives, they are not only read or typed but are being edited by women (in some cases) who have no desire to perpetuate patriarchy (Gauntlett, 2008, p. 199). So these may be one of the major reasons for increasing media coverage of women 's issues. However, despite the fact that more women are entering the field of journalism, those who rule the newsroom are predominantly men (Creedon, 1993, as cited in Beck, 1998). Women 's position in media is therefore still not powerful enough to overcome the gender discrimination.

According to a report of Samuha (2016), there are very less women in higher designation of media house. Further the report reveals the data that out of 907 media houses in the country, there are 21.1 percent of female journalists in Kathmandu valley (capital) and 26.7 percent outside Kathmandu valley. It means there are more males in the newsroom as well as for managing such media houses. About a decade ago, the representation was 10 percent only (Lama, 2008). Further this number from Federation of Nepalese Journalists (FNJ) do not count for all the active female journalists as they still count the memberships of women who have left the profession.

However according to Malla (2011), women constituted 12.9 percent as media personnel in 1991. Though there is slight difference in the data but we can see the improvement and increasing participation of women in media comparatively. However, the crux is still the same: there are less females reporting in media world in Nepal. There is also some discrimination in the areas allocated for male and female journalists to do the reporting. Female journalists are generally asked to do soft news and male journalists, hard news. Rodgers and Thorson (2018) investigated the news coverage of male and female reporters at three U.S. daily newspapers to determine whether gender differences result in reporting differences. Results of the content analysis revealed reporter differences due to gender for sourcing, story topic, and story tone in that female reporters drew upon a greater diversity of sources, stereotyped less, and wrote more positive stories than did male reporters. The size of the newspaper and ratio of male-to-female reporters and editors mediated these differences to a large degree.

According to Lama (2008), media owners and male editors have a kind of perception towards female journalists that acts as a barrier to provide equal responsibility among male and female journalists. She further says: "They think women journalists can't walk alone in night, can't travel anywhere, scared to fight with challenges, understand very little about political issues, has to be involved in household works and thus don't readily adopt journalism profession and even after they become journalist, they do not wish to continue it for many years or sustain within this profession (p.81).

However, the general secretary of Samuha reports the positive sides of it. The secretary went further to say: "I don't think that media has become biased as it was in the past. The news prepared by female journalists is not completely ignored now because the society at present is seeking the voice of women. The progress is not outstanding or as we have expected but there have been some positive changes.

Like Samuha, there has been many other organizations working to achieve gender equality in the country and has been continuously putting effort and thinking about how women's issues can be included in the mainstream media and how journalists, editors and managing bodies of media house be more gender sensitiveness towards the gender issues. 


\section{Research Design}

For the purpose of achieving the objectives of the study and understanding the issues thrown up by the research problem, the researcher used mixed methods approach. This approach is in tandem with Njoku et al......Int. J. Inno. Psychology \& Social Development 6(4): 1-11, 2018, Creswell \& Clark (2011), cited in Creswell (2012), where he posits that a mixed-methods research design is a method of gathering, analysing, and "mixing" both quantitative and qualitative data in a single study, or a series of studies, in order to understand a research problem.

The method is proved to be the most convenient and effective method of studies in the Social Sciences as Communication and media; and in this case, gender issues amongst female journalists. This method will not only lead to the proper validation of the research results, but is also aimed at deepening and widening one's understanding of the phenomenon, resulting to substantial and reliable conclusion. It is therefore the aim of the researcher to mix both quantitative and qualitative research approaches in order to harness the advantages inherent in each of them in one study. Considering the aim of this research, which is to get the views of both female journalists and editors in Lagos State on ascertaining the role of gender in career visibility amongst female journalists in selected Nigerian national dailies, it was deemed necessary by the researcher during the period of investigation to collect both quantitative and qualitative data sequentially in accordance with the chosen research design. Thus, for the purpose of this study, while survey (quantitative) was used to collect primary data, in-depth interviews (qualitative) was used to collect supplementary data. This means, the qualitative data was used as supportive to augment the quantitative where information is not provided by the latter. According to Creswell (2012), augmentation helps to gather information that typically addresses a different question from that asked for by the primary form of data.

\subsection{Population of the Study}

The data obtained from Nigerian Union of Journalists, Lagos Council, was a total number of 5,529. The study, however, targeted female journalists and Editors of various print media organisations in the above state given that both party were in the best position to clear the air on gender and career visibility amongst female journalists in Nigeria.

Populations of Registered Journalists

\begin{tabular}{|l|l|l|l|l|l|l|}
\hline Male & Female & Unisex & Repetition & $\begin{array}{l}\text { Blank } \\
\text { Space }\end{array}$ & $\begin{array}{l}\text { Incomplete } \\
\text { Names }\end{array}$ & Total \\
\hline 3,669 & 1,550 & 128 & 69 & 19 & 94 & 5,529 \\
\hline
\end{tabular}

Source: Nigerian Union of Journalists, 2020.

\subsubsection{Sample Size and Sampling Technique}

Samples for the survey were selected purposively. The researcher sampled every practicing female journalist found in the national newspaper organisations. The justification for this selection was that female respondents were in a better position to respond to an issue concerning them and the total number of female journalists found in the national newspaper organisations, 57, was a manageable sample size.

Sample Size Distribution

\begin{tabular}{|l|l|l|l|}
\hline Serial Number & Organisation & $\begin{array}{l}\text { Dailies Desk } \\
\text { Journalists }\end{array}$ & Online Journalists \\
\hline 1 & New Telegraph & 5 Work \\
\hline 2 & This Day & 2 [ No \\
Active Newsroom] & $\begin{array}{l}\text { [ No } \\
\text { Active Newsroom] }\end{array}$ \\
\hline 3 & Vanguard & $12 \quad 12$ & 2 \\
\hline 4 & Guardian & 14 & 2 \\
\hline 5 & Daily Sun & 4 & $\begin{array}{l}\text { Work } \\
\text { From Home }\end{array}$ \\
\hline 6 & & & 4 \\
\hline 7 & Daily Independent & 6 & $\begin{array}{l}\text { Work } \\
\text { From Home }\end{array}$ \\
\hline
\end{tabular}


Since the researcher intended interviewing the editors of various selected national newspaper organizations which could also be referred to as the researcher carrying out a descriptive phenomenological study, according to Creswell (1998), the researcher purposively selected the dailies editor per media house which equaled to a total of 7 participants for an experienced interview and additional 1 who was referred by the dailies editor, guardian newspaper to enrich this research work.

Purposive sampling was also used in the selection process of the seven media organizations. The researcher's selection was based on the common and major newspapers people are fond of. The number selected from each organization is as presented below:

Sample Distribution

\begin{tabular}{|l|l|}
\hline Media Organization & Sample Selected \\
\hline New Telegraph & 1 \\
\hline This Day & 1 \\
\hline Vanguard & 1 \\
\hline Guardian & 1 \\
\hline Daily Sun & 1 \\
\hline Daily Independent & 1 \\
\hline The Nations & 1 \\
\hline Total & $7+1($ Referred $)=8$ \\
\hline
\end{tabular}

Source: Nigerian Union of Journalists, 2020.

\subsubsection{Data Source, Collection and Method of Analysis}

The researcher's method of data analysis was both quantitative and qualitative. Answers extracted via the questionnaire were recorded as numeral data. The frequency of each answer was found and the percentage computed accordingly. Statistically, tables were used to present these data.

More so, answers extracted from the in-depth interview was analysed thematically which involved identifying, coding and categorizing themes from qualitative data generated. The Thematic analysis was chosen as the method of data analysis for this research because it is one of those qualitative approaches that help at arriving "at an understanding of a particular phenomenon from the perspectives of those experiencing it" (Vaismoradi, Turunen, and Bondas, 2013, p.398) through the organisation of the similarities in their experiences under parallel headings (themes). Data gotten form the survey and in-depth interview formed the basis for answering of the research questions.

\section{Analysis of Data \& Presentation of Results}

This chapter is for presentation, analysis and interpretation of data gathered through the use of questionnaire as well as key informant interview (KII). 
4.1. Presentation of Survey Findings

Frequency and Percentage Distribution of Respondents on Socio-Demographic Characteristics

\begin{tabular}{|c|c|c|c|}
\hline $\mathbf{S} / \mathbf{n}$ & Questions & Frequency & Percentage \\
\hline 1. & $\begin{array}{l}\text { Organizations represented } \\
\text { Guardian } \\
\text { Vanguard } \\
\text { This Day } \\
\text { Daily sun } \\
\text { New Telegraph } \\
\text { Nations } \\
\text { Daily Independent } \\
\text { Total }\end{array}$ & $\begin{array}{l}16 \\
14 \\
3 \\
4 \\
5 \\
6 \\
10 \\
58\end{array}$ & $\begin{array}{l}27.6 \% \\
24.1 \% \\
5.2 \% \\
6.9 \% \\
8.6 \% \\
10.3 \% \\
17.2 \% \\
100.0 \%\end{array}$ \\
\hline 2. & $\begin{array}{l}\text { Positions occupied } \\
\text { Sub editor } \\
\text { Editor of a desk } \\
\text { Writer } \\
\text { Others } \\
\text { Total }\end{array}$ & $\begin{array}{l}3 \\
10 \\
41 \\
4 \\
58\end{array}$ & $\begin{array}{l}5.2 \% \\
17.2 \% \\
70.7 \% \\
6.9 \% \\
100.0 \%\end{array}$ \\
\hline 3. & $\begin{array}{l}\text { Years of experience } \\
1-5 \text { years } \\
6-10 \text { years } \\
11-15 \text { years } \\
16 \text { and above } \\
\text { Total }\end{array}$ & $\begin{array}{l}19 \\
12 \\
19 \\
8 \\
58 \\
\end{array}$ & $\begin{array}{l}32.8 \% \\
20.7 \% \\
32.8 \% \\
13.8 \% \\
100.0 \% \\
\end{array}$ \\
\hline 4. & $\begin{array}{l}\text { Marital Status } \\
\text { Single } \\
\text { Married } \\
\text { Total }\end{array}$ & $\begin{array}{l}25 \\
33 \\
57\end{array}$ & $\begin{array}{l}43.1 \% \\
55.2 \% \\
100.0 \%\end{array}$ \\
\hline 5. & $\begin{array}{l}\text { Religion } \\
\text { Christianity } \\
\text { Muslim } \\
\text { Total }\end{array}$ & $\begin{array}{l}53 \\
5 \\
58\end{array}$ & $\begin{array}{l}91.4 \% \\
8.6 \% \\
100.0 \%\end{array}$ \\
\hline
\end{tabular}

Source: Fieldwork, 2021.

Extent to which female journalists employed in Nigerian national dailies enjoy career visibility

Table 4.1.2: Frequency and Percentage Distribution of Respondents based on the number of female journalists employed in Nigeria National Dailies

\begin{tabular}{|l|l|l|l|}
\hline S/n & Questions & Frequency & Percentage \\
\hline 1. & There has been increase in the number of practicing & & \\
& female journalist employed in the media house & 34 & $58.6 \%$ \\
& Yes & 6 & $10.3 \%$ \\
& Maybe & $6 \%$ & $31.0 \%$ \\
& No & 18 & $100.0 \%$ \\
\hline 2. & Total & 58 & \\
& There has been an increase in the number of women & & $39.7 \%$ \\
& Yes & 23 & $15.5 \%$ \\
& Maybe & 9 & $44.8 \%$ \\
& No & 26 & $100.0 \%$ \\
\hline 3. & Total & 58 & \\
& Are practicing female journalist allocated a balanced & & \\
& proportion of subjects/sources in the most prestigious & & $32.8 \%$ \\
& Yes & & $5.2 \%$ \\
& Maybe & 19 & $62.1 \%$ \\
& No & 3 & $100.0 \%$ \\
\hline
\end{tabular}

Source: Fieldwork, 2021. 
The extent gender is a factor in the career visibility of female journalists in Lagos State

Table 4.3: Frequency and Percentage Distribution on the Extent to which Gender is a Factor in the Career Visibility of Female Journalists

\begin{tabular}{|l|l|l|l|}
\hline S/n & Questions & Frequency & Percentage \\
\hline 1. & Gender served as a causal agent for hindering growth & & \\
& Yes & 25 & $43.1 \%$ \\
& Maybe & 4 & $6.9 \%$ \\
& No & 29 & $50.0 \%$ \\
& Total & 58 & $100.0 \%$ \\
\hline & Extent to which gender influences career visibility of & & \\
& female journalists & \\
& Negative influence on career visibility of female & 22 & $37.9 \%$ \\
& Positive influence on career visibility of female & 4 & $6.9 \%$ \\
& No Response & 32 & $55.2 \%$ \\
& Total & 58 & $100.0 \%$ \\
\hline
\end{tabular}

Source: Fieldwork, 2021.

Response of the female journalists to the possible hindering effect of gender on their career visibility in Lagos State

Table 4.4: Frequency and Percentage Distribution of Respondents base on the possible Hindering Effect of Gender on Career Visibility.

\begin{tabular}{|l|l|l|l|}
\hline S/n & Questions & Frequency & Percentage \\
\hline 1. & Causative factors hindering female journalist & & \\
& career visibility: & & \\
& Marriage & 7 & $17.1 \%$ \\
& Tradition & 10 & $24.4 \%$ \\
& Stereotype in the type of news covered & 19 & $46.3 \%$ \\
& Staying late at work & 3 & $4.9 \%$ \\
& No causative factor & 2 & $7.3 \%$ \\
& Total & 41 & $100.0 \%$ \\
\hline 2. & Effect of the hindrances on female on their & & \\
& career visibility: & & \\
& Stunted growth & 24 & $41.4 \%$ \\
& Overwhelmed/Stressed & 5 & $8.6 \%$ \\
& The need to pick family over work & 1 & $1.7 \%$ \\
& No effect & 28 & $48.3 \%$ \\
& Total & 58 & $100.0 \%$ \\
\hline
\end{tabular}

Source: Fieldwork, 2021.

Findings gathered through the in-depth interview guide indicated that there is a large difference in the number and positions occupied by both practicing gender in the print media and the above difference is as a result of one's passion, dedication, efficiency and result produced in term of number of bylines. Also, the distribution in the category of both soft and hard news is based on one's preference or interest of writing. In addition, some of the issues raised as factors limiting their career visibility were marriage, family, tradition, security issues amongst others. Consequently, the second research question was answered by admitting that gender does not serve as a causal agent and one's determination to get to her peak is personal. Furthermore, results proved that the factors limiting their career visibility (such as; marriage, family, tradition, security issues amongst others) were more of personal pros and cons put into consideration by individuals and not the board. Lastly, the researcher observed that for the female journalists to attain certain height, she has to be willing to sacrifice her time.

\section{Conclusion \& Recommendations}

The following conclusions are drawn from the findings presented above: 
$>$ Based on the findings of this study, it was concluded that the career visibility of the female journalists in Lagos State, Nigeria remains subject to some personal intervening variables significantly moderating inequality in the news room. These variables, as found by the study, include marriage, family, tradition, security issues amongst others. In the same light, preference, interest, passion, dedication, hard work and efficiency are key ingredients needed to break through the so-called glass ceilings in the media industry. To this end, it is important that when trying to solve the issue of gender and career visibility, one should put into cognisance the factors stated to have been limiting their progress and solutions this study found out in order to accomplish career visibility or career relevance in the print media industry.

$>$ Adequate security should be provided for the female practicing journalists who has shown interest and persistence in digging out relevant information from a dangerous environment. This will indicate the backing of the organization as a whole and her relevance in the organization.

$>$ Given how sensitive gender issues have proven to be in Nigeria and other places, there is need for periodic internal review of performances of staff in Nigerian print media organisation. This could be done under the umbrellas of bodies like the Nigeria Union of Journalists (NUJ), Nigerian Guild of Editors (NGE), among others. The aim will be to continually appraise how much practitioners (male and female) have been efficient in the duties assigned to them.

\section{REFERENCES}

1. Boateng, Kodwo Jonas Anson. 2017. "Reversal of Gender Disparity in Journalism Education- Study of Ghana Institute of Journalism.” Observatorio (OBS*) 11 (2): 118-135. doi:10.15847/ obsOBS11220171019.

2. Creswell, J. W. (1998). Qualitative Inquiry and Research Design: Choosing Among Five Traditions. Thousand Oaks, CA: Sage Publications. DC: World Bank). p. 22.

3. Debra Baker Beck. 1998. The "F" Word: How the Media Frame Feminism. The Johns Hopkins University Press. Vol. 10, No. 1 (Spring, 1998), pp. 139-153. https://www.jstor.org/stable/4316558.

4. Edström, Maria. 2017. "Is There a Nordic Way? A Swedish Perspective on Achievements and Problems with Gender Equality in Newsrooms." Medijske Studije 2 (3): 64-74.

5. Enwefah, C. (2016). Gender representation in the editorial and reportorial staff of newspapers in Nigeria. Global Journal of Human-Social Science: Arts \& Humanities-Psychology, 16(1), 16- 21.

6. Gallagher, M. (2001). Gender setting: new agendas for media monitoring and advocacy. London: Zed Boo ks in association with WACC, London.

7. Global Media Monitoring Project. 2015. GMMP 2015 Reports. http://whomakesthenews.org/gmmp-2015

8. Global_Media_Monitoring_Project (2020). Who_Makes_the_News_-_.pdf Accessed on 18 ${ }^{\text {th }}$ March, 2021.

9. Gray, F.E. \& Hessell, N. (2014). Gender and journalism: Women and/in the news in the nineteenth century. Nineteenth-century gender studies. Floyd, S. and Purdue, M. (Eds.)

10. Karthika C., Rajeev, P; Midhila, M. S. (2019). Work and life of women journalists: A study in special refer ence to Karela. International Journal of Innovative Technology and Exploring Engineering (IJTTEE), Volu me 8, Issue 7 (2019). https://www.ijitee.org/wp-content/uploads/papers/v8i7s2/G10540587S219.pdf.

11. N. Birdsall, A.j. Ibrahim, G.R. Gupta (2004). Background Paper for the Task Force on Education and Gender Equality of the Millennium Project. "Promises to Keep: Achieving Gender Equality and the Empowerment of Women”. Washington, DC: International Center for Research on Women.

12. Ngozi Njoku, Uloma, Harcourt Whyte Dike, Rosemary Vincent. 2018. Journalism Practice and Gender Constraints: A Survey of Female Journalists in Port Harcourt. (PDF) Journalism Practice and Gender Constraints: A Survey of Female Journalists in Port Harcourt (researchgate.net)

13. North, Louise. 2016. "The Gender of Soft and Hard News." Journalism Studies 17 (3): 356-373. doi:10.1080/1461670X.2014.987551.

14. Okunna, C.S. (1992). Female faculty in journalism education in Nigeria: Implications for the status of women in the society. African Media Review, 6(1), 47-58.

15. Okunna, C.S. (2000). Mass media gender images and the Nigerian girl child. [in CD ROM]. Paper presented at Summit 2000: on Youth, Children and the Media.

16. Safa, M.N. \& Akter, T. (2015). Challenges of female journalists in Bangladesh. Humanities and Social Sciences, 3(5), 207-214. 
17. Sanusi, B.O. \& Adelabu, O.T. (2015). Women in journalism practices in Nigeria: From the hood to the limelight. Journal of Research and Development, 2(6), 1-7.

18. Steiner, Linda. 2012. "Failed Theories: Explaining Gender Difference in Journalism." Review of Communication 12 (3): 201-223.

19. Usher, Nikki, Jesse Holcomb, and Justin Littman. 2018. "Twitter Makes It Worse: Political Journalists, Gendered Echo Chambers, and the Amplification of Gender Bias." The International Journal of Press/Politics 23 (3): 324-344. 